\title{
PRIORITY SECTOR LENDINGS IN THE POST REFORM PERIOD
}

\author{
1 Dr. R. Amutha
}

\begin{abstract}
Priority Sector Lending has become an essential component of national agenda after the nationalization of banks. The list of sectors included in priority sector lending has changed with time. Major changes in priority sector lending is seen after the initiation of banking sector reforms in 1991. The study attempt to analyse the performance of public sector banks' advances under priority sector lendings. The period of the study is 1991 to 2009 and is divided into two parts. PSBs' achieved and surpass the stipulated target (40 percent of NBC) during the second half of the study period. In Agriculture Advance they have failed to keep pace with the rate at which both NBC and priority sector lendings have increased. Banks appear to have partially forgotten their responsibilities in lending to SSIs and weaker sections in the period after reform. The percentage share of priority sector NPAs is quite high as compared to its share in NBC. Shrinking share of real priority sector, neglect of agriculture coupled with its sub optional structure, neglect of SSIs, and mounting NPAs in priority sector lending are some serious issues, which need immediate attention. Hence, banks should adopt a balanced approach as development agent and ensuring sustainability of directed lending.
\end{abstract}

\section{INTRODUCTION}

The socialization of bank credit has been the theme of priority sector lendings by the Public Sector Banks. The nationalization of fourteen major commercial banks in 1969 and six in 1980, alongwith the adoption of multi agency approach in the five years plans induced the banks to divert their attention from "class banking" to "mass banking". Since then, banks concentrate their efforts on lending to priority sector which included hitherto neglected sectors, such as agriculture, small scale industries (SSIs), cottage industries rural artisans and craftsmen and other weaker sections. As banks touch the lives of millions, it is their top most responsibility to help the government in achieving the different socio-economic priorities like growth of agriculture, small scale industries, exports, raising employment levels, encouragement of entrepreneurs and development of backward areas. This designated priority and hitherto neglected sector received only 15 percent of the total credit on the eve of bank nationalization. The changing role of banks resulted in increasing the proportion of advances to priority sector from 15 percent to 33.3 percent in 1974 and further to 40 percent in 1980.

To start with priority sector included only agriculture (direct and indirect), SSI's and industrial estates, road and water transport operators, retail trade, small business professional and self-employed person and education. In the year 1980, on the basis of recommendations of Krishna Swamy Group weaker sections (small and marginal farmers, landless labourers, SC/ST etc.) were also included in the priority sector. The Ghosh Group (1982) made important recommendations regarding the nature of agriculture advances and targeting of direct and indirect farm lending. Narshimam Committee (1991) highlighted the problems of low and declining profitability in the public sector banks and recommended for the gradual phasing out of directed credit programmes. The committee emphasized that priority sector should redefined and the proportion of credit flow under this should be fixed at 10 per cent of aggregate credit. However, in view of its strategic

1 Amutha Srinivasan, Mobile : 9790744509 , E-mail : cityoflotus@gmail.com 
role, which priority sector is expected to play in fulfilling various economic and social objectives, Government of India did not accept this proposal. Though subsequently Narshimam Committee (1998) acknowledged the political compulsions faced by the Government with respect to curtailment of priority sector lendings yet, again persisted that it must be brought down to 10 per cent. Since the initiation of banking sector reforms in 1991, priority sector lendings have seen some major changes. Considering the relevance of priority sector lendings, an attempt is made in this study to discuss the issues relating to its growth and structure.

\section{REVISED GUIDELINES ON PRIORITY SECTOR LENDING}

Based on the Draft Technical Paper submitted by the Internal Working Group (Chairman: Shri C.S. Murthy) and the feedback received thereon from the Governments, banks, financial institutions, non-banking financial companies, associations of industries, media, public and Indian Banks' Association, the guidelines on lending to priority sector were revised on April 30, 2007. The guiding principle of the revised guidelines on lending to the priority sector has been to ensure adequate flow of bank credit to those sectors of society/ economy that impact large segments of the population, the weaker sections and to the sectors which are employment-intensive, such as agriculture and tiny and small enterprises. The broad categories of advances under the priority sector now include agriculture, small enterprises sector, retail trade, microcredit, education and housing, subject to certain limits. The major changes made in the guidelines are set out below :

(i) In order to overcome the crowding out effect against small loans, particularly to agriculture, big-ticket loans/ advances have been kept out of the direct agriculture segment (loans/advances in excess of Rs. 1 crore granted to corporates, will get only one-third weightage for being counted under direct agriculture).

(ii) With a view to encouraging direct and retail lending by banks, intermediation has been generally discouraged by keeping loans for on-lending, barring a few. (iii) Some of the banks had a 'nil' or negligible net bank credit (NBC) and were engaging mostly in non-funded business (derivatives). This distortion has been sought to be corrected by linking their targets to the credit equivalent of their off balance-sheet business.

(iv) The overall priority sector lending targets at 40 per cent and 32 per cent for the domestic and foreign banks respectively, as also other sub-targets, have been retained unchanged. However, these are now calculated as a percentage of adjusted net bank credit (ANBC) or credit equivalent amount of off-balance sheet exposures (OBE), whichever is higher, instead of NBC. ANBC includes NBC plus investments made by banks in non-SLR bonds held in HTM category. In order to address the problem faced by banks in pursuing a moving target the reference $A N B C$ or credit equivalent of OBE for the purpose of the targets has been stipulated as ANBC or credit equivalent of OBE as on $31^{\text {st }}$ March 31 of the proceeding year.

(i) Certain concessions granted earlier for the purpose of priority sector (i.e., exclusion of FCNR(B) / NRNR deposits from NBC) have lost their relevance in an environment of substantially large foreign exchange reserves. Such concessions have, therefore been withdrawn. The outstanding FCNR(B) and NRNR deposits balances would no longer be deducted for computation of ANBC for priority sector lending purposes.

\section{LITERATURE REVIEW :}

There have been number of studies concerning different aspects of priority sector lendings by the public sector banks. In addition to pointing out the different reasons for poor quality of priority sector lendings Chawala (1979), Bhat (1980) and Srinivasan (1995) observed that it is mainly relatively well-off only, who got the benefit of priority sector lending and poorest of poor remained credit starved. Shette (2002) observed that despite an expansion in the definition 
of priority sector lendings, the flow of credit to priority sector substantially came down in the decade of 1990s. Majumdar (1996 \& 1998), Mohanti (1997) and Shajahan (1998) found the impact of financial sector reforms on priority sector lending quite adverse. On account of financial sector reforms, the public sector banks involvement in growth process of the economy has been quite adversely affected, as they are moving away from directly lending to priority sector. Agarwal, Puhazhendhi and KJS Satyasai (1997); Puhazhendhi and Jayaraman (1999) and Reddy (2001), particularly pointed out the neglect of agriculture in priority sector lendings during the post reform period. Even RBI (2001) in its report also admitted that there has been a deceleration in credit disbursal to small and marginal farmers in the decade of 1990s. In addition to Nayak Committee (1993) and Kapoor Committee (1998), certain individual researchers i.e. Kohli (1997), Kulkarni \& Kaveri (2004) attempted to analyse issues concerning low credit off-take to SSI's sector. It was emphasized that since the needs of SSI are increasing, there is a need to make a review of credit supply to this sector from the point of view of policies, systems and procedures and arrangements etc.

In addition to these, certain other dimensions relating to priority sector lendings i.e. problem of NPAs and subsequent poor profitability have also been studied. For example, Singh (1996), a study conducted by RBI (1999) and Misra (2001) found priority sector lendings as one of the major reasons for NPAs of public sector banks. Ambumani \& Niranjana (1993) study supported the hypothesis that priority sector lendings are the main culprit behind low profitability of public sector banks. In contrast, studies conducted by Amandeep, Chakrabarty (1990), Anand (1992) and Kohli (1997) do not find any clear cut evidence linking directed credit programme in India to low profits exhibited by the public sector banks.

\section{METHODOLOGY}

In the present paper an attempt is made to analyse growth and structure of priority sector lendings by public sector banks in the post reform period in India. The study aims at highlighting certain relevant issues thus arising. Time period selected in the study is stretched over the years 1991 to 2009 . With a view to study changing pattern of growth and structure of priority sector lendings, the selected time period is divided into two parts. The first part includes the year 1991 to 1997 and the second part covers the period 1998-2009. There are basically two reasons for dividing the time period in this way. Firstly, it is expected that in the initial few years of financial reforms banks must have taken some time to adjust in the new economic environment, so the picture immediate after the reforms in no way can be taken as truly representative of the trend. Secondly, it is the year 1998, since when performance of banks has taken a "U”' turn (D'Souza, 2002; Ram Mohan, 2002; Kapoor, 2004), hence, the period since 1998 must be studied separately.

\section{OBJECTIVE}

The objective of the present study is to evaluate the performance of public sector banks with regard to advances under priority sectors during the post reform period.

\section{HYPOTHESIS}

The performance of Public Sector Banks with regard to priority sector lending is better during the second half of the study period.

\section{TRENDS IN PRIORITY SECTOR ADVANCES}

The most important issue which arises in context to priority sector lendings is regarding its growth and structure in the post reform period. The growth of net bank credit and priority sector advance is exhibited in Table - 1 .

\section{Table - I}

Advances to Priority Sector by Public Sector Banks (Amount in Rs. Crores)

\begin{tabular}{|l|c|c|c|}
\hline Period - I & NBC & TPSAs & $\begin{array}{c}\% \text { of TPSAs } \\
\text { in NBC }\end{array}$ \\
\hline 1991 & $1,02,959$ & 42,093 & 40.88 \\
\hline 1992 & $1,14,502$ & 44,995 & 39.30 \\
\hline 1993 & $1,31,231$ & 47,846 & 36.46 \\
\hline 1994 & $1,36,003$ & 52,525 & 38.46 \\
\hline
\end{tabular}




\begin{tabular}{|c|c|c|c|}
\hline Period - I & NBC & TPSAs & $\begin{array}{c}\% \text { of TPSAs } \\
\text { in NBC }\end{array}$ \\
\hline 1995 & $1,69,038$ & 61,794 & 36.55 \\
\hline 1996 & $1,84,391$ & 69,584 & 38.36 \\
\hline 1997 & $1,89,684$ & 79,102 & 41.72 \\
\hline AVG. & $1,46,830$ & 56,848 & 38.72 \\
\hline GR (IN\%) & & 10.79 & \\
\hline \multicolumn{4}{|l|}{ Period - II } \\
\hline 1998 & $2,18,219$ & 91,295 & 41.84 \\
\hline 1999 & $2,46,203$ & $1,07,200$ & 43.54 \\
\hline 2000 & $2,92,943$ & $1,27,05 t$ & 43.62 \\
\hline 2001 & $3,41,291$ & $1,49,116$ & 43.69 \\
\hline 2002 & $3,96,954$ & $1,71,185$ & 43.13 \\
\hline 2003 & $4,77,899$ & $2,03,095$ & 42.50 \\
\hline 2004 & $5,58,849$ & $2,45,672$ & 44.00 \\
\hline 2005 & $7,17,304$ & $3,10,093$ & 43.20 \\
\hline 2006 & $10,17,656$ & $4,09,74 \oint$ & 40.30 \\
\hline 2007 & $13,13,840$ & $5,21,37 \varnothing$ & 39.7 \\
\hline 2008 & $13,64,268$ & $6,10,450$ & 44.70 \\
\hline 2009 & $16,93,437$ & $7,20,083$ & 42.50 \\
\hline AVG. & $7,19,905$ & $2,98,683$ & 42.0 \\
\hline GR (IN\%) & 16.23 & & \\
\hline 'P' VALUE & 3.923 & 3.778 & \\
\hline
\end{tabular}

Note :- Figures in column 2 represent percentage to net bank credit. Since 2007-08, these figures, represent percentage to adjusted net bank credit.

Source : Report on Trends and Progress of Banking in India, Relevant Issues.

Though there has been no formal instruction to the public sector banks to curtail priority sector lendings, somehow there appears to be some hidden instruction to them to cut short these lendings (Shajahan 1998) in the post reform period. With the adoption of banking reforms becoming part and parcel, the percentage share of priority sector lendings in net bank credit came down from

40.88 per cent in 1991 to all time low of 36.55 per cent in the year 1995. Nevertheless from the year 1996 onwards the ratio appears to have started improving. For example, during the year 1996 and 199739.36 per cent and 41.72 per cent respectively of net bank credit was being deployed in the priority sector. However, if the average ratio of priority sector lendings to NBC for the first half of the study (1991 to 1997) is taken into account, inspite of relatively higher priority sector lendings in the years 1991 and 1997, 38.82 per cent of net bank credit was deployed in priority sector.

During the second half of the study (1998 to 2009), situation appears to have changed atleast at the surface level, as evident from the fact that a much higher share (on an average 42.0 per cent) of net bank credit was deployed in priority sector lendings. Not only that, in contrast to 10.79 per cent rate of growth registered during the first phase, the priority sector lendings also registered a much higher rate of growth of 16.23 per cent during the second part of the study. Further, it could be seen that PSBs not only achieved the stipulated target (40 percent) but also surpassed it in almost all year during the second half. As the 'P' value for total priority sector advances for the study periods is 3.788 , it may be inferred that there is significant difference in the deployment of advances to priority sector during the study period.

\section{AGRICULTURAL ADVANCES UNDER PRIORITY SECOTR CREDIT}

The public sector banks appear to have been doing reasonably well at the surface level with respect to priority sector lendings. The inside story however appears to be somewhat different. Probably this high ratio of priority sector advances is on account of number of guidelines coming up from RBI from time to time evolving different methods through which advances from direct priority sector lendings can take place. For example, in 1996, the RBI asked the banks to invest in SFC, REC, SIDCS, NABARD, SEB and Investments made by the banks in special bonds issued by these agencies are also treated as priority sector lendings. Further, banks facing a shortfall in achieving the priority sector target were advised to 
provide Rs. 10 billion as a consortium basis to Khadi and Village Industries Commission at an interest rate of 1.5 per cent below the average prime-lending rate of five major banks. The changes thus made in the policy guidelines with respect to priority sector lendings appear to help the banks to enable them to move away from the responsibility of directly lending to the zeal priority sector of the economy.

Recently lots of changes have taken place in the definition of priority sector, the relevance of priority sector lendings can be rightly judged only if the structure of priority sector lendings is examined thoroughly. The upcoming issue is the changing structure of priority sector advances is in accordance with our national priorities, or these lendings have become just a ritual or are a form of face saving exercise by the banks. As agriculture is the foundation of Indian economic system, it should be the first responsibility of the public sector banks to deploy required finances to this sector. In the year 1969, agriculture accounted for as low as 7 per cent of total bank credit and therefore was considered as one of the major reasons of bank nationalization.

\section{TABLE - II}

\section{Agriculture Advances Under Priority Sector Credit}

(Amount in Rs. Crores)

\begin{tabular}{|l|c|c|c|}
\hline Period - I & $\begin{array}{c}\text { Total } \\
\text { Credit }\end{array}$ & $\%$ to NBC & \% toTPSAs \\
\hline 1991 & 16864 & 16.40 & 40.06 \\
\hline 1992 & 18460 & 16.10 & 41.04 \\
\hline 1993 & 19874 & 14.80 & 41.33 \\
\hline 1994 & 20739 & 15.30 & 39.48 \\
\hline 1995 & 23612 & 13.90 & 41.29 \\
\hline 1996 & 26351 & 14.30 & 37.87 \\
\hline 1997 & 31012 & 16.30 & 39.20 \\
\hline Avg. & $\mathbf{2 2 4 1 6}$ & $\mathbf{1 5 . 3 0}$ & $\mathbf{4 0 . 1 0}$ \\
\hline
\end{tabular}

\begin{tabular}{|l|l|l|c|}
\hline Period - II & $\begin{array}{c}\text { Total } \\
\text { Credit }\end{array}$ & \% to NBC & \% toTPSAs \\
\hline 1998 & 34305 & 15.70 & 37.58 \\
\hline 1999 & 40078 & 16.30 & 37.39 \\
\hline 2000 & 46190 & 15.80 & 37.23 \\
\hline 2001 & 53571 & 15.70 & 37.52 \\
\hline 2002 & 63082 & 15.90 & 37.88 \\
\hline 2003 & 73507 & 15.38 & 36.19 \\
\hline 2004 & 86186 & 15.41 & 35.08 \\
\hline 2005 & 112747 & 15.68 & 36.36 \\
\hline 2006 & 155220 & 15.30 & 37.88 \\
\hline 2007 & 202614 & 15.40 & 38.60 \\
\hline 2008 & 249397 & 18.2 & 40.82 \\
\hline 2009 & 298211 & 17.60 & 41.41 \\
\hline Avg. & $1,17,926$ & 16.03 & 39.83 \\
\hline
\end{tabular}

Source : Report on Trends and progress of Banking in India, Relevant Issues.

In Table II Agriculture advance under priority sector lendings by the public sector banks during the post reform period is exhibited. Agriculture advances when explained as percentage of total priority sector lendings, stood on an average at 40.10 per cent during the first seven years and fell to 39.83 per cent, during the latter period of the study. Agriculture advances as percentage of NBC throughout stood less than the desired norm of 18 per cent.

In contrast to 15.3 per cent during the first period, the public sector banks deployed marginally higher percentage of NBC i.e., 16.03 per cent in agriculture during the second period, and thus failed to achieve the desired target. Whether it is the first period or the second, agriculture advances have failed to keep pace with the rate at which both net bank credit and priority sector lendings have increased. Somewhat smaller rate of growth of agriculture advances coupled with reduced percentage allocations of priority sector lendings to agriculture and failure of the banks to achieve the desired norm are going to have serious implications for Indian economy. In addition, the banks have also been found shy of meeting different sub-targets of agriculture lendings (Table III). 


$$
\text { Table - III }
$$

\section{SUB-TARGETS OF AGRICULTURE FINANCING UNDER PRIORITY SECTOR LENDING}

(Amount in Rs. Crores)

\begin{tabular}{|c|c|c|c|c|}
\hline \multirow[b]{2}{*}{ Period - I } & \multicolumn{2}{|c|}{ Direct Agriculture Finance } & \multicolumn{2}{|c|}{ Indirect Agriculture Finance } \\
\hline & Amount & $\%$ to NBC & Amount & $\%$ to NBC \\
\hline 1991 & 15782 & 15.30 & 1082 & 1.10 \\
\hline 1992 & 17020 & 14.90 & 1440 & 1.30 \\
\hline 1993 & 18332 & 13.80 & 1542 & 1.00 \\
\hline 1994 & 18765 & 13.80 & 1974 & 1.50 \\
\hline 1995 & 20812 & 12.30 & 2800 & 1.60 \\
\hline 1996 & 22892 & 12.40 & 3659 & 1.90 \\
\hline 1997 & 25826 & 13.60 & 5186 & 2.70 \\
\hline Avg. & 19918 & 13.56 & 2526 & 1.72 \\
\hline \multicolumn{5}{|c|}{ Period - II } \\
\hline 1998 & 28303 & 13.00 & 6002 & 2.80 \\
\hline 1999 & 31681 & 12.90 & 8397 & 3.40 \\
\hline 2000 & 34432 & 11.80 & 11758 & 4.00 \\
\hline 2001 & 38137 & 11.20 & 15434 & 4.30 \\
\hline 2002 & 44908 & 11.30 & 18174 & 4.60 \\
\hline 2003 & 51799 & 10.84 & 21707 & 4.54 \\
\hline 2004 & 61957 & 11.08 & 24229 & 4.30 \\
\hline 2005 & 83038 & 11.6 & 26879 & 3.7 \\
\hline 2006 & 112126 & 11.0 & 43093 & 4.2 \\
\hline 2007 & 144372 & 11.2 & 58242 & 4.4 \\
\hline 2008 & 176135 & 12.9 & 72550 & 5.3 \\
\hline 2009 & 215635 & 12.7 & 81223 & 4.5 \\
\hline Avg. & 85,210 & 11.9 & 32307 & 4.17 \\
\hline
\end{tabular}

Source : Report on Trends and Progress of Banking in India, Relevant Issues. 
Presently, out of 18 per cent of net bank credit prescribed for agriculture, maximum limit determined for direct agriculture credit is 13.5 per cent and of indirect agriculture credit is 4.5 per cent by the public sector banks. As against this norm on an average 13.56 per cent and 11.79 percent of NBC was deployed as direct and indirect agriculture credit during both the periods respectively. A careful analysis of the data reveals that during the period 1998 to 2009 the percentage share of direct agriculture credit in net bank credit has continuously fallen down. Even in the years 2003 and 2004, as little as 10.84 per cent and 11.08 per cent of agriculture credit was of the kind of direct finance. As a combined effect of all the above mentioned facts, despite an improved rate of growth recorded by direct agriculture advances its percentage share in total agriculture lending came down to 11.79 per cent during the second period. On the contrary, the percentage share of indirect agriculture credit which on an average stood at 1.72 of total NBC in the first phase rose to 4.17 per cent in the second period. What follows out of the analysis is that the overall target of agriculture lending has not only remained largely unfulfilled, but the public sector banks have also failed to achieve the sub-targets of agriculture lending (more particularly of direct agriculture lending). It is important to mention there that this picture of agriculture finance that has emerged is despite the fact that the scope of direct agriculture credit under priority sector lending has been widened so as to include all short term advances to traditional plantations including tea, coffee, rubber and spices irrespective of the size of holding.

The increased share of indirect finance is also neither on account of loans given for distribution of fertilizers and other inputs, nor due to loans given to electricity boards and to farmers through PACs/FSS, but on account of the head 'other type of indirect finance'. Thus, when in the year 1991 the percentage share of this category (other type of indirect finance) in net bank credit stood at 1.10 per cent, in the year 2002 its' share rose to 4.60 per cent. What follows out of the discussion is that not only the share of agriculture in net bank credit has declined, the structure of agriculture finance has also been changing.

\author{
TABLE - IV
}

SMALL SCALE INDUSTRIES ADVANCES UNDER PRIORITY SECTOR LENDING

(Amount in Rs. Crores)

\begin{tabular}{|c|c|c|c|}
\hline Period - I & $\begin{array}{c}\text { Total } \\
\text { Credit }\end{array}$ & \% to NBC & \% toTPSAs \\
\hline 1991 & 16590 & 16.10 & 39.41 \\
\hline 1992 & 17689 & 15.50 & 39.29 \\
\hline 1993 & 18841 & 14.10 & 39.38 \\
\hline 1994 & 21309 & 15.60 & 40.57 \\
\hline 1995 & 25843 & 15.30 & 41.82 \\
\hline 1996 & 29482 & 16.30 & 42.30 \\
\hline 1997 & 31542 & 16.60 & 39.88 \\
\hline Avg. & 23042 & 15.64 & 40.39 \\
\hline Period II & & & \\
\hline 1998 & 38109 & 17.50 & 41.74 \\
\hline 1999 & 42674 & 17.30 & 39.81 \\
\hline 2000 & 45788 & 15.60 & 36.91 \\
\hline 2001 & 48400 & 14.20 & 33.90 \\
\hline 2002 & 49743 & 12.50 & 29.37 \\
\hline 2003 & 52988 & 11.08 & 26.01 \\
\hline 2004 & 58278 & 10.40 & 23.72 \\
\hline 2005 & 67634 & 9.40 & 21.81 \\
\hline 2006 & 82434 & 8.10 & 20.11 \\
\hline 2007 & 102550 & 9.50 & 19.66 \\
\hline 2008 & 151137 & 11.1 & 24.75 \\
\hline 2009 & 191307 & 11.3 & 26.56 \\
\hline Avg. & $1,07,086$ & 9.88 & 28.69 \\
\hline
\end{tabular}

Source : Report on Trends and progress of Banking in India, Relevant Issues.

As far as credit given to SSIs is concerned, here also the banks appear to have partially forgotten their responsibilities in lending to this strategic sector of Indian economy in the period after reforms. The data contained in Table IV indicates that during the first 
seven years of the study, 15.64 per cent of net bank credit was deployed in SSIs and thereafter this ratio further declined to 9.88 per cent during the second half of the study. If credit deployed in SSIs is explained as a proportion of total priority sector advances, the SSIs appear to be even a greater losser. In contrast to 40.39 per cent in the first period, only 28.69 per cent of priority sector lendings was deployed in SSIs during the second period. The share of priority sector advances to SSIs should be viewed in context to both dilution of priority sector definition and due to redefining of SSIs by RBI. It redefined SSIs with investment in plant and machinery worth up to 6 million (Rs. Seven million in case of ancillary units and export oriented units). At the same time the bank credit to SIDCs and SFCs was also taken as priority sector loans. There are number of studies (D'Souza, Ram Mohan 2002 and Kapoor 2004) which point out that the profitability position of public sector banks has taken a U turn from the year 1998, incidentally it is the year from where onwards banks lendings to SSIs is continuously falling. Whereas in the year 1998, 41.74 per cent of priority sector and 17.5 per cent of net bank credit was deployed in SSIs, by the year 2009, after witnessing a continous fall, these values settled at 26.56 per cent and 11.3 per cent respectively.

\section{TABLE - V}

\section{OTHER PRIORITY SECTOR UNDER PRIORITY SECTOR LENDING}

(Amount in Rs. Crores)

\begin{tabular}{|l|l|l|c|}
\hline Period - I & $\begin{array}{c}\text { Total } \\
\text { Credit }\end{array}$ & $\%$ to NBC & $\%$ toTPSAs \\
\hline 1991 & 8639 & 8.40 & 20.52 \\
\hline 1992 & 8842 & 7.70 & 19.65 \\
\hline 1993 & 9234 & 7.00 & 19.30 \\
\hline 1994 & 10477 & 7.70 & 19.95 \\
\hline 1995 & 12439 & 7.40 & 20.13 \\
\hline 1996 & 13751 & 7.50 & 19.76 \\
\hline 1997 & 16548 & 8.70 & 20.92 \\
\hline Avg. & 11419 & 7.77 & 20.03 \\
\hline
\end{tabular}

\begin{tabular}{|l|l|l|c|}
\hline Period - II & $\begin{array}{c}\text { Total } \\
\text { Credit }\end{array}$ & \% to NBC & \% toTPSAs \\
\hline 1998 & 18881 & 8.70 & 20.88 \\
\hline 1999 & 24448 & 9.90 & 22.81 \\
\hline 2000 & 32079 & 11.00 & 25.86 \\
\hline 2001 & 40791 & 12.00 & 28.57 \\
\hline 2002 & 53712 & 13.50 & 32.25 \\
\hline 2003 & 71448 & 14.95 & 35.18 \\
\hline 2004 & 94959 & 17.00 & 38.61 \\
\hline 2005 & 129984 & 18.1 & 41.91 \\
\hline 2006 & 163756 & 16.1 & 39.95 \\
\hline 2007 & 206661 & 15.72 & 39.63 \\
\hline 2008 & 209842 & 15.4 & 34.37 \\
\hline 2009 & 230507 & 13.61 & 32.01 \\
\hline Avg. & $1,06,422$ & 13.83 & 32.67 \\
\hline
\end{tabular}

Source : Report on Trends and progress of Banking in India, Relevant Issues.

Within the priority sector, it is the category 'other priority sector' which appears to be the first choice of public sector banks. During the first seven years on an average 7.7 per cent of NBC and 20.03 per cent of total priority sector advances was deployed in this category. However, on account of exceptionally high rate of growth recorded with respect to lendings in 'other priority sector', during the second half of the study its share in total priority sector advances and NBC on an average swelled to 32.67 per cent and 13.83 per cent during the latter period (Table $\mathrm{V}$ ). This high ratio is on account of the raising of the existing ceiling limits on advances to 'other priority sector' such as retail trade, small business enterprises, housing and professional and self employed persons under this particular category of priority sector in the post reform period. In October 1997 the scope of priority sector credit to road transport operators was widened by increasing the number of eligible vehicles from six to ten. Credit to road and water transport operations for purchase of vehicles was also raised. The limit of priority sector credit to housing in rural and urban areas was also raised, thus leading to such a high ratio. 


\section{ADVANCE TO WEAKER SECTIONS UNDER PRIORITY SECTOR LENDING :}

One important way to judge the performance of public sector banks with respect to priority sector lendings can be in terms of their financing to weaker sections of the society. Being an important social agent, the public sector banks are supposed to lend a minimum of 10 per cent of their NBC among the weaker sections. An analysis of data contained in Table VI reveals that though in the years 1991 and 1992 the public sector banks were quite close to the stipulated target of 10 per cent of NBC to be deployed among the weaker sections. The banks in the new economic environment however appear to have deviated from their basic social responsibility of removal of poverty to a large extent. In the year 1999, the public sector banks came quite close to the desired target and infact in the year 2000 (for the first time) they achieved the required norm as well, yet they miserably failed to sustain their performance in the ensuing years. Since the year 2000, the banks have been deploying just 7 per cent of their NBC among weaker sections. It is interesting to note that in 2008 and 2009 there is a change in trend, and are close to the stipulated target of 10 percent of NBC. The failure in achieving the set norm is despite the fact that in the post reform period even the definition of weaker sections has also undergone a change.

\section{TABLE - VI}

\section{ADVANCES TO WEAKER SECTIONS UNDER PRIORITY SECTOR LENDING}

(Amount in Rs. Crores)

\begin{tabular}{|l|c|c|c|}
\hline Period - I & $\begin{array}{c}\text { Advances } \\
\text { made to }\end{array}$ & \% to TPSAs & \% to NBC \\
\hline 1991 & 10246 & 24.24 & 9.70 \\
\hline 1992 & 10879 & 24.40 & 9.70 \\
\hline 1993 & 11817 & 24.29 & 8.90 \\
\hline 1994 & 12823 & 24.14 & 9.10 \\
\hline 1995 & 13861 & 24.43 & 8.20 \\
\hline 1996 & 15673 & 24.51 & 8.50 \\
\hline 1997 & 16312 & 20.61 & 8.60 \\
\hline Avg. & $\mathbf{1 3 0 8 7 . 2 9}$ & $\mathbf{2 3 . 8 0}$ & $\mathbf{8 . 9 6}$ \\
\hline
\end{tabular}

\begin{tabular}{|l|c|c|c|}
\hline Period - II & $\begin{array}{c}\text { Advances } \\
\text { made to }\end{array}$ & $\%$ to TPSAs & $\%$ to NBC \\
\hline 1991 & 10246 & 24.24 & 9.70 \\
\hline 1998 & 18985 & 20.79 & 8.70 \\
\hline 1999 & 24374 & 22.74 & 9.90 \\
\hline 2000 & 32223 & 25.21 & 11.0 \\
\hline 2001 & 24884 & 16.98 & 7.20 \\
\hline 2002 & 28580 & 17.16 & 7.30 \\
\hline 2003 & 32303 & 15.91 & 6.76 \\
\hline 2004 & 41588 & 16.93 & 7.44 \\
\hline 2005 & 63492 & 20.47 & 8.85 \\
\hline 2006 & 78373 & 19.12 & 7.7 \\
\hline 2007 & 94284 & 18.09 & 7.20 \\
\hline 2008 & 126934 & 20.84 & 9.3 \\
\hline 2009 & 166843 & 23.17 & 9.9 \\
\hline Avg. & 61072 & 19.78 & 8.44 \\
\hline
\end{tabular}

Source : Report on Trends and progress of Banking in India, Relevant Issues.

Not only some new sections have been included in the category of weaker sections, the borrowal limit for small and marginal farmers has also been removed. In the decade of 1980's and early 1990's the definition of weaker sections was quite different from the one prevailing since the year 1995. Earlier small and marginal farmers were those who had a holding of 5 acres or less, and persons engaged in allied activities with borrowal limit up to Rs.10,000 were to be treated as weaker sections. But as per the definitions of 1995 , the borrowal limit was removed. On the other hand, new categories and beneficiaries of SUME, SLPS schemes and self help groups under NABARD have also been brought into the ambit of weaker sections.

\section{NON-PERFORMING ASSETS OF PRIORITY SECTOR LENDING}

Any discussion of priority sector remains incomplete if the issue of its sustainability is not taken up. The sustainability of priority sector depends upon how efficiently credit is recycled in the priority sector in an economy and that issue is directly linked with the level of priority sector NPA's. 
Table -VII

NON-PERFORMING ASSETS OF PUBLIC SECTOR BANKS 1996 - 2009

(Amount in Rs. Crores)

\begin{tabular}{|c|c|c|c|c|c|c|c|}
\hline \multirow{2}{*}{ Period } & \multicolumn{2}{|c|}{ Priority Sector } & \multicolumn{2}{c|}{ Non-Priority Sector } & \multicolumn{2}{c|}{ Public Sector } & \multirow{2}{*}{$\begin{array}{c}\text { Total } \\
\text { NPAs }\end{array}$} \\
\cline { 2 - 7 } & Amount & $\begin{array}{c}\text { \% to } \\
\text { Total NPAs }\end{array}$ & Amount & $\begin{array}{c}\text { \% to } \\
\text { Total NPAs }\end{array}$ & Amount & $\begin{array}{c}\text { \% to } \\
\text { Total NPAs }\end{array}$ & \multirow{2}{*}{ NPA } \\
\hline 1996 & 19106 & 48.3 & 19067 & 48.2 & 1411 & 3.6 & 39584 \\
\hline 1997 & 20774 & 47.7 & 21341 & 49.0 & 1461 & 3.4 & 43577 \\
\hline 1998 & 21184 & 46.4 & 27608 & 50.6 & 1362 & 3.0 & 45653 \\
\hline 1999 & 22606 & 43.7 & 28524 & 53.4 & 1496 & 2.9 & 51710 \\
\hline 2000 & 23715 & 44.5 & 23707 & 53.5 & 1055 & 2.0 & 53294 \\
\hline 2001 & 24159 & 45.4 & 28405 & 51.4 & 1711 & 3.2 & 53174 \\
\hline 2002 & 25156 & 46.2 & 26781 & 52.2 & 903 & 1.7 & 54458 \\
\hline 2003 & 24939 & 47.2 & 25697 & 50.7 & 1087 & 2.1 & 52807 \\
\hline 2004 & 23840 & 47.5 & 3.56 & 51.2 & 610 & 1.2 & 50148 \\
\hline 2005 & 23397 & 49.5 & 23848 & 50.0 & 450 & 0.9 & 476961 \\
\hline 2006 & 22374 & 54.7 & 18664 & 45.1 & 340 & 0.8 & 41378 \\
\hline 2007 & 22953 & 59.6 & 15157 & 39.0 & 490 & 1.3 & 38601 \\
\hline 2008 & 25286 & 63.6 & 14163 & 35.6 & 298 & 0.8 & 39748 \\
\hline 2009 & 24318 & 55.2 & 19251 & 43.7 & 474 & 1.1 & 44042 \\
\hline
\end{tabular}

Source : Report on Trends and progress of Banking in India, Relevant Issues.

The data contained in Table VII reveals a grim situation regarding the growing level of NPAs in the priority sector lendings. Two serious observations made are firstly, that the percentage share of priority sector NPAs turns out to be quite high as compared to it's share in NBC. For example in the year 1996, 97, 98 the share of priority sector NPAs in total NPAs stood 48.3 per cent, 47.7 per cent and 46.4 per cent respectively than the Priority Sector advance share in NBC. Though the position with respect to NPAs improved in 1999 in the sense that priority sector NPAs recorded all time low figure and it's share in total NPAs dropped approximately equal to its share in NBC. However, again particularly from the year 2001 onwards the differences between priority sector NPAs and its' corresponding share in NBC has started increasing. The second important observation made is that priority sector NPAs have recorded a marginally higher proportion as compared to non priority sector lendings. However the high volume of NPA's carried forward in the succeeding years might have led to such results.

Sector-wise NPA's position of public sector banks depicted in Table IX reveals that in priority sector NPAs highest share is that of SSIs followed by agriculture and other priority sector. 
Table - IX

Sector-wise NPAs of Priority Sector Lendings

(In percentage)

\begin{tabular}{|l|c|c|c|c|}
\hline Period & Agriculture & SSIs & OPS & Weaker Section \\
\hline 2001 & 13.87 & 19.44 & 12.11 & 22.51 \\
\hline 2002 & 13.84 & 18.73 & 11.92 & 20.81 \\
\hline 2003 & 14.60 & 19.24 & 13.39 & 19.39 \\
\hline 2004 & 14.44 & 17.62 & 15.48 & 18.90 \\
\hline 2005 & 15.21 & 16.43 & 17.42 & 13.15 \\
\hline 2006 & 14.99 & 16.72 & 22.36 & 8.45 \\
\hline 2007 & 16.86 & 15.14 & 27.47 & 6.57 \\
\hline 2008 & 20.80 & 14.60 & 28.21 & 5.39 \\
\hline 2009 & 13.0 & 15.9 & 26.4 & 4.1 \\
\hline
\end{tabular}

Source : Report on Trends and progress of Banking in India, Relevant Issues.

Whereas the share of agriculture and other priority sector in total NPAs has always stood less than their corresponding share in priority sector lending, in case of SSIs vice-versa was observed. This is the reason probability on account of which lending to SSIs have been so severely hit in the post reform period. As far as advances made to weaker sections are concerned this too appears to be an important source of priority sector NPAs. Further there exists a large gap between credit disbursed to this section and their corresponding share in NPAs.

\section{CONCLUSION}

.In brief, shrinking share of real priority sector, neglect of agriculture coupled with its' sub-optimal structure, neglect of small scale industries are some serious issues which need immediate attention of the policy makers. Banks appear to be deviating from their role of a social agent, by not paying the required assistance to the weaker sections in the post reform period. Further, there appears to be some serious doubts about the sustainability of the system of priority sector lending as evident from its volume of NPA's. Public sector banks should at no cost give up their developmental role even in today's changed economic environment. However the problem of NPA's too cannot simultaneously be altogether neglected. Hence, public sector banks need to go for a very balanced approach regarding their role as development agent and at the same time must ensure the sustainability of directed lendings too.

\section{REFERENCES :}

I Agarwal, K.P., V.Puhazendhi and K.J.S.Satyasai, (1997), "Gearing Rural Credit for Twenty First Century", Economic and Political Weekly, Vol.XXXII, No.42, October 18, pp.2717-2728.

I Amandeep, (1990), "Profits and Profitability of Indian Nationalized Banks", Ph.D. Thesis, Punjab University, Chandigarh

I Anand, S.S, (1992), "In Priority Sector Lending till a Drag on Profitability?" The Banker, October 1992, pp 35-43.

I Anbumain, V and S.Niranjana, (2001), "Social Objectives and Priority Sector Lending", in Amalesh Banerjee and S.Kumar Singh (ed.) Banking and Financial Sector Reforms in India, Deep and Deep Publication, Delhi, pp.241. 
I Chakrabarty (1990), "Banking in 1990's", Himalaya Publishing House, Bombay.

I Chawla, A.S (1979), "Nationalization and Growth of Indian Banking", Deep and Deep Publication, Delhi.

I D'Souza, Errol (2002), "How Well Have Public Sector banks Done? A Note", Economic and Political Weekly, Vol.XXXVII, No., March 2-8, 2002, pp.867-870.

I Das, Hem Chandra lal, (2001), "Priority Sector lendings by Public Sector Banks under Financial Sector Reforms in India", The Indian Economic Journal, Vol.47, No.2, October 2001, pp.246-263.

I Narasihman Committee, (1990), "Report of the Committee on the Financial System", December, 1990, Delhi.

I Narasihman Committee, (1998), "Report of the Committee on Financial Sector Reforms-II", April, 1998 Delhi.

I Kapoor, G.P, (2004), "Commercial Banking", A.P.h. Publishing Corporation, Delhi.

I Kapoor Committee, (1998), "Report of Committee on Credit to SSIs", Reserve Bank of India, Mumbai.

I Kohli, Renu, (1997), "Directed Credit and Financial Reforms", Economic \& Political Weekly, Vol.XXXII, No.42, October 18, 1997, pp.2267-2276.

I Kulkarni and Kaveri, (2005), "Roe of Financial Market for SMEs in India”, Prajnan, Vol.XXXIV, No.1, April-June, 2005, pp.63-79.

I Majumdar, N.A. (1995), "New Banking Culture and Small Borrowers", Economic and Political Weekly, Vol.XXX, No.35, September 2, 1995, pp.2169-2170.

I Majumdar, N.A. (1996-97), "Development Imperatives and the Banking System", Prajnan, Vol.XXV, No.3-4, pp.245-251.

I Majumdar, N.A., (1998), "Banking Sector Reforms, Second Coming”, Economic \& Political Weekly, Vol.XXXIII, No.47 and 48, November 21-27/28 December 4, 1998, pp.2954-2957.
I Majumdar, N.A. (1998), "Credit Support to Priority Sector - A Macro Perspective", Economic and Political Weekly. Vol.XXXII, No.4, January 24, 1998, pp.147-152.

I Misra S.N. and Sriram Misra, (2001), "Development of Commercial Banking under Financial and Banking Sector Reforms: Problems, Achievements and Prospects", in Amalesh Banerjee \& S.Kumar Singh (ed.) Banking and Financial Sector Reforms in India, Deep \& Deep Publication, Delhi.

I Mohanti, Subhash, (1997), "Banks Parting Funds with SDBI and NABARD", The Economic Times, No.6.

I Nayak Committee, (1993), "Report to Examine the Adequacy of the Institutional Credit to SSI Sector and Related Aspects", Reserve Bank of India, Mumbai.

I Patel, K.V. and V.S.Kaveri, (1998), "NonPerforming Advances in Priority Sector", IBA Bulletin, Vol.20, No.6, pp.16.

I Puhazhendhi and Jayaraman, (1999), "Rural Credit Delivery: Performance and Challenges before Banks", Economic and Political Weekly, Vol.XXXI, No.3-4, January 16-23, pp.175-182.

I Ram Mohan, T.T, (2002), "Deregulation and Performance of Public Sector Banks", Economic and Political Weekly, Vol.XXXVII, No.5, February 2-8, pp.393-397.

I RBI, (1982), "Role of Banks in Implementation of 20 Point Programme", Ghosh Working Group, Mumbai.

I RBI, (2001), "Report on Currency and Finance", Vol.2000-01

I Reddy, Y.K, (2001), "Address at the Annual Conference of Indian Society of Agricultural Marketing", Vizag, ISAM, February 3, 2001.

I Shajahan, K.M., (1999), "Priority Sector Lendings, How Useful", Economic and Political Weekly, Vol.XXXIV, No.51, December 18, 1999, pp.3572-3574. 
I Shahjahan, KM, (1998), "Priority Sector Bank Lendings; Some Important Issues", Economic and Political Weekly, Vo.XXII, No.42, 43, October 17-24, 1998, pp.2749-2752.

I Shette, N.B., (2002), "Priority Sector Advances of Banks during the Post Reform Perod", Prajnan, Vo.XXXI, No.1, pp.21-26.
I Singh, Shrawan Kumar, (2000), "Banking Sector Reforms Some Issues with Problem of NPAs", Paper presented in IEA Annual Conference, Calcutta University.

I Srinivasan, R, (1995), "Priority Sector Lending, A Study of India Experience", Prajnan, Vol.XXIV, No.2, pp.168-172. 